\title{
Self Compacting Concrete under Local Conditions
}

\author{
Abderahmane Seddik $^{1}$, Ahmed Beroual ${ }^{2}$, Abdesselam Zergua ${ }^{2}$, Mohamed Nacer Guetteche ${ }^{2}$ \\ ${ }^{1}$ Department of Civil Engineering, Ferhat Abbas University, Setif, Algeria \\ ${ }^{2}$ Department of Civil Engineering, Constantine 1 University, Constantine, Algeria \\ Email: mnguetteche@yahoo.fr
}

Received April 7, 2013; revised May 10, 2013; accepted May 17, 2013

Copyright (C) 2013 Abderahmane Seddik et al. This is an open access article distributed under the Creative Commons Attribution License, which permits unrestricted use, distribution, and reproduction in any medium, provided the original work is properly cited.

\begin{abstract}
This paper presents the results of experimental investigations on mechanical properties of self compacting concrete made with local materials. The used materials were cement, aggregate and super plasticizer. Limestone powder, silica fume and blast furnace slag have been used as adjuvant in self compacting concrete (SCC). Self compacting concrete properties in fresh and hardened state are characterized and analyzed. The test results indicate the possibility to manufacture SCC with good rheological and mechanical properties using local materials.
\end{abstract}

Keywords: Self Compacting Concrete (SCC); Mineral Additions; Super Plasticizer; Workability; Compressive Strength and Tensile Strength

\section{Introduction}

In recent years, there has been an important increase in the use of self-compacting concrete (SCC) [1-6]. Since its emergence, SCC is widely used all over the world. SCC was developed in Japan to improve the uniformity and reliability of concrete [7]; it doesn't require any consolidation work at site. The characterization and formulation of this material have been the subject of numerous investigations [8-11].

Using SCC in structures would result in both technical and economical advantages. One of the most important differences between SCC and conventional concrete is the incorporation of a mineral admixture. This concrete is characterized by a high amount of fines, an amount of water, a relatively low use of super plasticizers, a high deformability and good uniformity in such a way that it can flow under its own weight to completely fill the formwork and passes through the congested reinforcement without any mechanical vibration. Many studies show the advantage of mineral admixture usage in SCC; and it enables to improve the workability with a reduction of cement content [12-14]. The mineral admixtures enable to improve particle packing, to decrease the permeability and to increase the durability of concrete [15]. The waste materials such as limestone powder, fly ash and granulated blast furnace slag are generally used as mineral admixtures in SCC [16-19] These add a positive impact on the timeliness and quality of concrete [7], at the same time the environmental pollution will be re- duced [20].

The aim of the present work is to highlight the influence of local constituents in the composition of a SCC from the viewpoint of fresh and hardened state behavior and therefore to develop optimized formulations with good rheological and mechanical properties.

This paper deals with the investigation of the effect of LP, BFS and SF as mineral admixtures on the fresh and hardened properties of SCC. Therefore, the saturation point with the cone Marsh, the slump flow, the compressive strength, the ultrasonic pulse velocity (UPV) and the dynamic elastic modulus tests were conducted to achieve this objective and determine the appropriateness of using these different material admixtures in SCC.

The experimental work began with the characterization of various local materials from Algeria.

\section{Experimental Program}

\subsection{Materials}

The materials used in this study were locally sourced and they satisfied the requirements of Algerian Standards.

\subsubsection{Cements}

Portland cement (CPA CEM I 42.5) is supplied by the cement-Ain Kebira-Algeria, according to EN 197/1 (European Committee for Standardization-2000) [10]. Its mineralogical composition is $\mathrm{C} 3 \mathrm{~S}=61.3 \%$, C2S $=$ $15.9 \%, \mathrm{C} 3 \mathrm{~A}=8 \%$ and $\mathrm{C} 4 \mathrm{AF}=9.6 \%$. 


\subsubsection{Aggregates}

The coarse aggregates are from a deposit of limestone (Kef-Erendira region, Eastern of Algeria). Its Los Angeles coefficient and absolute density are respectively $20 \%$ to $28 \%$, and the value of absolute density is equal to 2.7 . Natural sand, (fine aggregates) was procured from a nearby river source. It has a sand equivalent, fineness module and absolute density equal to $78 \%, 2.0$ and 2.60 respectively.

\subsubsection{Minerals Addition}

The addition included minerals are Silica fume with blain specific surface of $200,000 \mathrm{~cm}^{2} / \mathrm{g}$, local limestone fillers (type Alcal15), blast furnace slag (Blaine specific surface of $\left.4200 \mathrm{~cm}^{2} / \mathrm{g}\right)$.

\subsubsection{Super Plasticizers}

Super plasticizer by trade name MEDAFLOW 30 was used as high water reducing agent, third generation, to achieve the required workability.

\subsection{Principles of Mix Proportioning}

The portioning of the mix is extremely important in developing an effective SCC. The effect of mixture proportion, in terms of ratios between cement to solids and coarse and fine aggregates has been the subject of many investigations [21].

The incorporation of fine mineral remains empirical. There is no universally agreement on the effect of these factors due to the complexity of combined action.

Assuming that fresh concrete behaves as a material in two phases namely a viscous phase, consisting of the paste (cement + fines + water) and a granular phase containing all the aggregates. Preliminary concrete mixture (Table 1), was adopted as a control mix test; and the two phases are analyzed.

\subsection{Specimen Preparation}

The concrete was mixed using a mixer with a capacity of $100 \mathrm{l}$. The mixture sequence was as follows: all the solid components (natural aggregates, cement, silica fume, blast furnace slag and calcareous filler) were mixed for $30 \mathrm{~s}$. It was followed by the introduction of the effective water and one third of the super plasticizer. After $90 \mathrm{~s}$ of mixing, the remaining additives (the rest of the super plasticizer and the viscosity agent) were added and mixed with the other components for 210 s. Then the slump flow tests were carried out. Depending on the obtained test results, additives and/or water were adjusted. Specimens were cast in various moulds of different shapes according to the test requirements. Due to the flowing ability of fresh SCC, the materials were successfully poured directly into the moulds without vibration.
Table 1. Preliminary concrete mixture.

\begin{tabular}{|c|c|c|c|c|c|c|}
\hline Constituents & $\begin{array}{c}\text { Sand } \\
0 / 5\end{array}$ & $\begin{array}{c}\text { Aggregates } \\
3 / 8\end{array}$ & Cement & Water & $\mathrm{W} / \mathrm{C}$ & $\begin{array}{c}\text { Super } \\
\text { plasticizer }\end{array}$ \\
\hline Volume $\left(1 / \mathbf{m}^{3}\right)$ & 300 & 285 & 161.3 & l & I & 7 \\
\hline $\operatorname{Mass}\left(\mathrm{kg} / \mathrm{m}^{3}\right)$ & 780 & 770 & 500 & 175 & 0.35 & 7.5 \\
\hline
\end{tabular}

\subsection{Characterization of Fresh Concrete}

\subsubsection{Optimization of the Paste}

Optimization of the bonding paste is obtained using the Marsh cone test. The study focuses on the variation of flow time of different grout depending on the dosage of super plasticizers. Four grout mixtures were investigated. First mix don't contain any added mineral, the second one contains $10 \%$ of silica fume, the third mix contains $30 \%$ of limestone filler and the last mix contains $30 \%$ of blast furnace slag.

Figure 1 shows the variation of flow time for different mixes. It decreases with the increasing of super plasticizer dosage until reaching a certain point called the saturation point. After that, it remains nearly constant or with a slightly increase.

The flow time of the mix without mineral addition is $0.9 \%$ by weight of dry cement (Figure 1(a)). It is $1 \%$ for the mix with silica fume (Figure 1(b)), while it is $1.1 \%$ in the cases of the two others mixes (Figures 1(c) and (d)).

\subsubsection{Optimization of the Granular Skeleton}

The development of an effective SCC involves either modifying the cement paste, or tuning the aggregates, or both of them [20].

The interlocking of coarse aggregates is integral to the strength of the concrete [22].

With coarse aggregates, changing inter-particle spacing most practically changes the flow ability of concrete. Coarse aggregates tend to settle with the introduction of super plasticizer, which causes segregation.

Two proportions were studied in fresh state of SCC. The first mix contains $67 \%$ of gravel (3/8) and 33\% of coarse aggregates (large gravel) (8/15) while the second one contains $33 \%$ of gravel (3/8) and $67 \%$ of coarse aggregates $(8 / 15)$.

The mixtures of three sets of concrete for three different sand/paste ratios were manufactured with two mixes for each series. Only the quantities of fine aggregates and coarse aggregate were varied, while the other constituents were kept constant for the entire investigation. The water to binder ratio was also kept constant. The details of different series are given in Table 2.

Table 2 and Figure 2 show the effect of aggregate content on the large diameter of slump for water to binder ratio equal to 0.4 . 


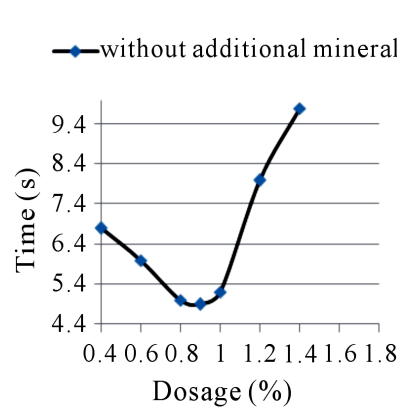

(a)

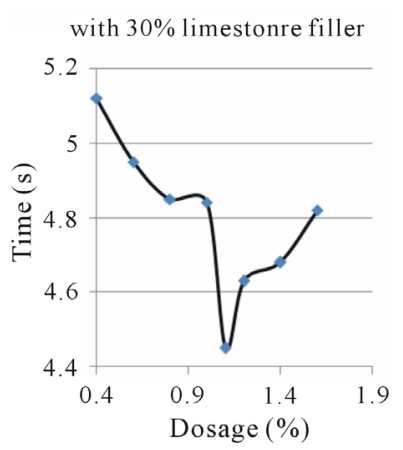

(c)

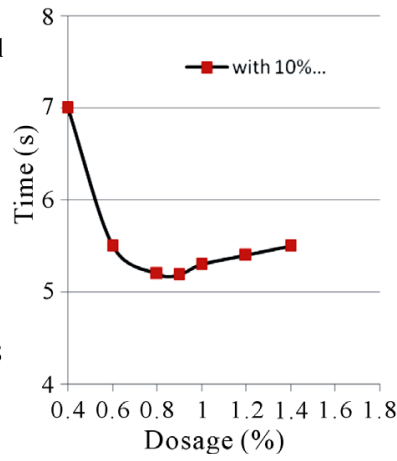

(b)

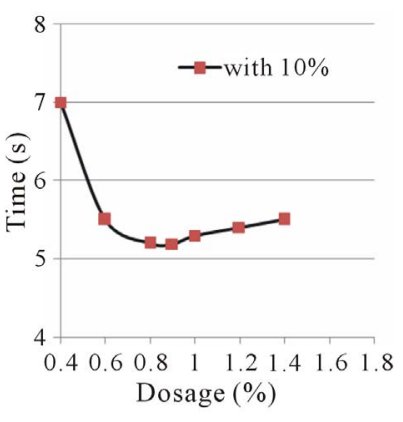

(d)

Figure 1. Flow time vs. super plasticizer dosage for different grouts.

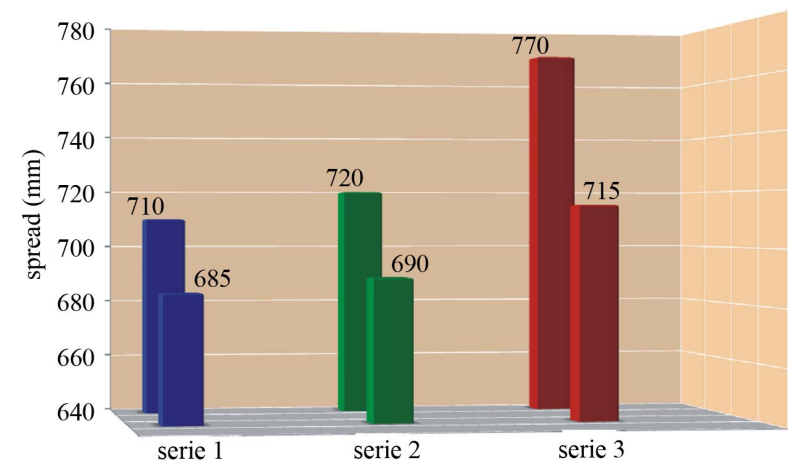

Figure 2. Coarse aggregates effect on the flow slump diameter (with $\mathrm{w} / \mathrm{b}=\mathbf{0 . 4})$.

It was found that the composition scc11, scc21, scc31 with the gravel proportion of $67 \%$ gives a better deformability and flexibility compared to other admixtures.

For series 1 with a sand/paste ratio equal to 0.81 , the improvement is averaging $3.6 \%$ between scc11 and scc12. This improvement in diameter is inversely proportional to the sand/paste ratio. This is a consequence of the reduction in the volume of large coarse aggregates and so reducing the braking phenomenon. These results are in accordance with those reported in [23].

The workability improvement of concrete is mainly due to the reduction of the content of large aggregates of class $(8 / 15)$, because the increase in the gravel diameter

Table 2. Coarse aggregates effect on the flow slump diameter $($ with $w / b=0.4)$.

\begin{tabular}{ccccccc}
\hline & \multicolumn{2}{c}{ Series 1 } & \multicolumn{2}{c}{ Series 2 } & \multicolumn{2}{c}{ Series 3 } \\
\cline { 2 - 7 } & $\begin{array}{c}\text { Scc11 } \\
\text { A1 }\end{array}$ & $\begin{array}{c}\text { Scc21 } \\
\text { A2 }\end{array}$ & Scc21 & $\begin{array}{c}\text { Scc22 } \\
\text { B2 }\end{array}$ & $\begin{array}{c}\text { Scc31 } \\
\text { C1 }\end{array}$ & $\begin{array}{c}\text { Scc32 } \\
\text { C2 }\end{array}$ \\
\hline Sand 0/5 & 780 & 780 & 780 & 780 & 780 & 780 \\
Gravel 3/8 & 516 & 254 & 516 & 254 & 516 & 254 \\
Coarse aggregates & 254 & 516 & 254 & 516 & 254 & 516 \\
$\mathbf{8 / 1 5}$ & 500 & 500 & 500 & 500 & 500 & 500 \\
Cement & 200 & 200 & 210 & 210 & 220 & 220 \\
Water & 7.5 & 7.5 & 7.5 & 7.5 & 7.5 & 7.5 \\
$\begin{array}{c}\text { Super plasticizer } \\
\text { Silica fume }\end{array}$ & $/$ & $/$ & 25 & 25 & 50 & 50 \\
$\quad$ w/b & 0.4 & 0.4 & 0.4 & 0.4 & 0.4 & 0.4 \\
$\begin{array}{c}\text { Spread diameter } \\
\text { (mm) }\end{array}$ & 710 & 685 & 720 & 690 & 770 & 715 \\
\hline
\end{tabular}

causes a braking action (especially in the case of crushed aggregates) and the frictions between particles which limit the material motion.

\subsubsection{Effect of Super Plasticizers Content on the Workability of SCC}

The purpose in using super plasticizers is to achieve highly flow able concrete while maintaining low water and high fines content.

In the slump flow test a standard slump cone is used and SCC is typically poured in without consolidation efforts. The flow diameter is the mean diameter measured in two perpendicular directions. Some researchers recommend a slump flow value between 500 to $700 \mathrm{~mm}$. Slump flow exceeding $700 \mathrm{~mm}$ could lead to segregation of the mix.

The analysis was carried out in concrete mixtures with three percentages of super plasticizer (respectively $0.8 \%$, $1.1 \%$ and $1.4 \%$ of cement weight). The specimens were tested to study the workability of concrete with local materials (Table 3).

Figure 3 shows that concrete workability increased with the increasing of the super plasticizers content. Note that for $0.8 \%$ of additional substance and with $\mathrm{w} / \mathrm{b}=0.35$, the self compacting concrete is not possible to manufacture.

\subsubsection{Effect of the Colloidal Agent Content on the Stability of SCC}

Stability is the characteristic of SCC to resist to the segregation. It is often quantified with the Visual Stability Index which ranges from 0 to 3 in increments of 0.5 [24].

The tested concrete mixtures are composed of $67 \%$ of gravel $(3 / 8)$ and $33 \%$ of coarse aggregate $(8 / 15)$. The cement is of $100 \%$ and w/c is equal to 0.35 . Four percentages of colloidal agents were used. The results are 
Table 3. The super plasticizer effect on the flow spread diameter.

\begin{tabular}{cccc}
\hline Constituent $\mathbf{( k g / \mathbf { m } ^ { \mathbf { 3 } } )}$ & SCC2 & SCC2 & SCC3 \\
\hline Sand 0/5 & 780 & 780 & 780 \\
Gravel 3/8 & 516 & 516 & 516 \\
Coarse aggregates 8/15 & 254 & 254 & 254 \\
Cement & 500 & 500 & 500 \\
Water & 189 & 189 & 189 \\
w/b & 0.35 & 0.35 & 0.35 \\
Super plasticizer & $5.5(1.1 \%)$ & $5.5(1.1 \%)$ & $7(1.4 \%)$ \\
Silica fume & 50 & 50 & 50 \\
Spread diameter (mm) & 565 & 565 & 620 \\
\hline
\end{tabular}

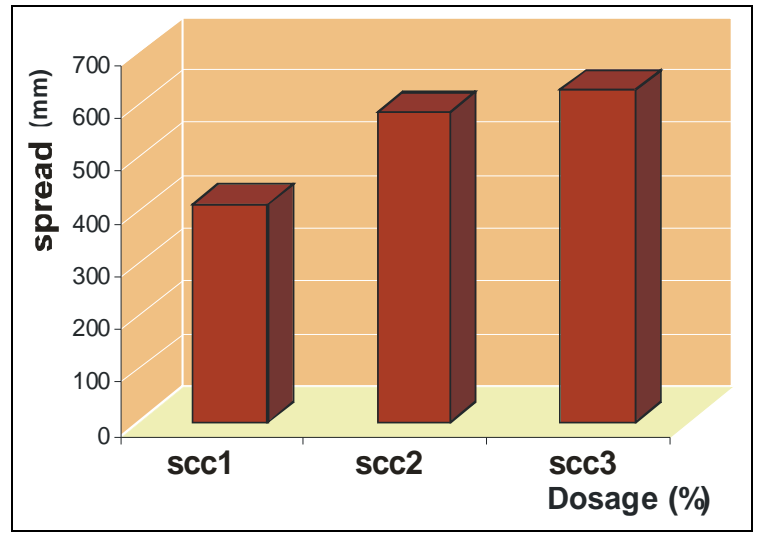

Figure 3. Super plasticizers content effect on spread diameter of a SCC.

given in Table $\mathbf{4}$ and Figures $\mathbf{4}$ and $\mathbf{5}$.

The interest of introducing a colloidal agent, is to guarantee a particular viscosity, good concrete stability and ensuring a better cohesion of the paste with maintaining a distance between the aggregates and then reducing their interaction and friction during collision. It is seen from Figures $\mathbf{6}$ and $\mathbf{7}$ that the increase of the viscosity agent leads to a decrease in segregation and spread diameter of concrete. The reduction of segregation and spread diameter is nearly linear.

\subsection{Specimen Preparation}

After testing the SCC in fresh state the concrete was poured in moulds of cubes and cylinders. The tests were conducted using a universal compression testing machine. The load was applied and increased continuously until the specimen breaks.

Compressive strength tests were carried out on cubes of $150 \mathrm{~mm}$ size. Split tensile strength tests were carried out on cylinders of $160 \mathrm{~mm}$ diameter and $320 \mathrm{~mm}$ height. Five concrete mixes were designed with a water/blinder ratio of 0.35 . In the first mixture the specimens were cast with only Portland cement while the others one a part of
Table 4. Spread diameter and segregation rate for different percentage of colloidal agent content on the fresh SCC.

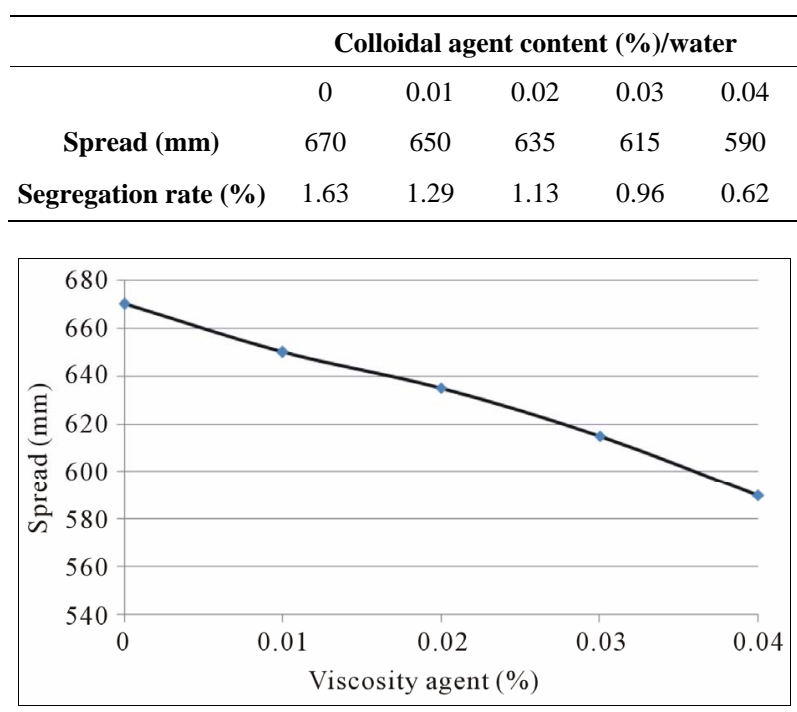

Figure 4. Spread diameter for different colloidal agent content.

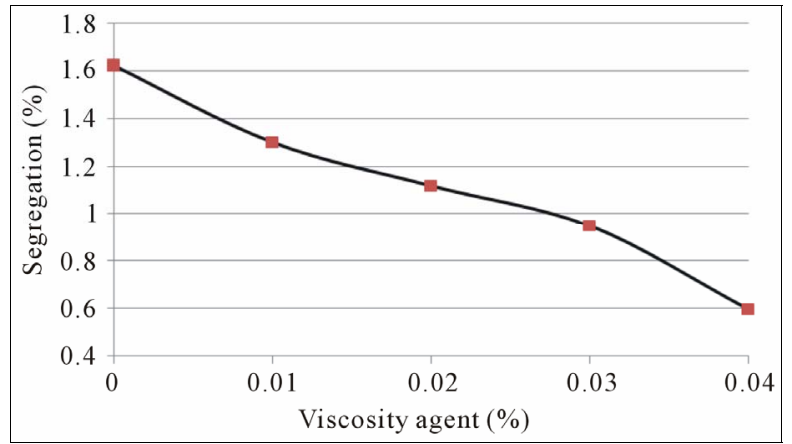

Figure 5. Segregation rate for different colloidal agent content.

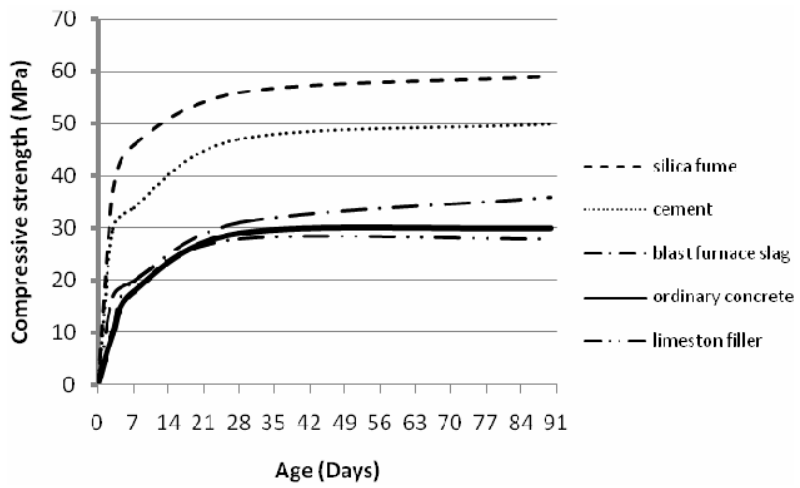

Figure 6. Compressive strength of concrete mixes.

cement was replaced respectively with blast furnace slag, limestone filler and silica fume. An ordinary concrete mix is used as control test. The proportions of constituent materials for all mixes are given in Table 5 and the results are presented in Figures 6 and 7. 
Table 5. Formulations of different SCC mixture.

\begin{tabular}{cccccc}
\hline Constituents $\left(\mathrm{kg} / \mathrm{m}^{3}\right)$ & scc1 & scc2 & scc3 & scc4 & oc \\
\hline Sand & 780 & 780 & 780 & 780 & 635 \\
Gravel & 516 & 516 & 516 & 516 & 642 \\
Coarse agregates & 254 & 254 & 254 & 254 & 642 \\
Cement & 500 & 350 & 350 & 500 & 350 \\
Silica fume & $/$ & $/$ & $/$ & 50 & $/$ \\
Blastfournace slag & $/$ & 150 & $/$ & $/$ & $/$ \\
Liestone filler & $/$ & $/$ & 150 & $/$ & $/$ \\
Water & 175 & 175 & 175 & 176 & 175 \\
w/b & 0.35 & 0.35 & 0.35 & 0.32 & 0.5 \\
Superplastifiant & 6 & 6 & 6 & 8 & $/$ \\
\hline
\end{tabular}

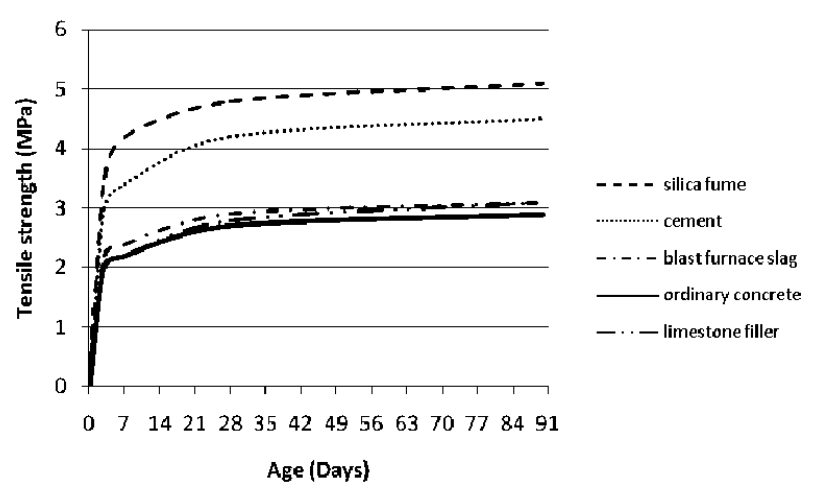

Figure 7. Splitting tensile strength of concrete mixes.

\subsection{Ultrasonic Pulse Velocity (UPV) and Dynamic Elastic Modulus}

Values of the ultrasonic pulse in $(\mathrm{m} / \mathrm{s})$ and the dynamic modulus of elasticity by ultrasound at the age of 28 days are presented in Table 6.

\section{Results and Discussion}

The slump-flow values for SCC with LP, BFS and SF are presented in Figure 1. All mixtures exhibited good workability with flow values of at least $580 \mathrm{~mm}$. Slump flows of $685 \mathrm{~mm}$ to $770 \mathrm{~mm}$ are typically required for SCC [25], and all the tested mixtures are in this interval. It appears that the flow time of a cement grout in the Marsh cone decreases with the increase of the super plasticizer content until a certain dosage then remains nearly constant. The saturation point is defined as the intersection of two linear parts of the curve. It is the limit between the decreasing part and the constant one. After this point the increase of super plasticizer content has no important impact on the grout rheology.

It is observed that the saturation points are respectively $0.9 \%, 1 \%$ and $1.1 \%$ by weight of cement for the mixtures without addition, with silica fume addition and with
Table 6. Ultrasonic pulse velocity (UPV) and dynamic modulus of elasticity by ultrasound.

\begin{tabular}{cccccc}
\hline & SCC1 & SCC2 & SCC3 & SCC4 & OC \\
\hline UPV (m/s) & 4409 & 4359 & 4232 & 4438 & 4255 \\
$\begin{array}{c}\text { Dynamic } \\
\text { modulus (GPa) }\end{array}$ & 40.99 & 39.20 & 37.34 & 43.65 & 38.18 \\
\hline
\end{tabular}

limestone filler and blast furnace slag. Generally, the flow time of grout without fine minerals is lower than those with additional ones.

Table 2 shows that the first formulation with the proportions (67\% of gavel (3/8) and 33\% of aggregates (8/16)), gives a better deformability and workability compared to the other composition. For a volume of sand to a volume of pulp ( $\mathrm{S} / \mathrm{P}=0.81)$, an improvement of $5.1 \%$ of spread diameter is observed in the case of the second formulation. However, for an $\mathrm{S} / \mathrm{P}=0.74$, the increase of the first combination is about $4.3 \%$ than the other ones and is about $2.1 \%$ for the $\mathrm{S} / \mathrm{P}=0.69$ comparing with the second formulation. The observed improvement in values of spread diameters is due to the reduced volume of coarse aggregate. These results are in a good accordance with those reported in [23].

Figures 2 and $\mathbf{3}$ show that reduction of w/l affects the behavior of fresh SCC based silica fume. The SCC with $\mathrm{w} / \mathrm{l}$ equal to 0.32 shows a decrease in the spread diameter of respectively about $11.53 \%$ and $22.61 \%$ compared to those with $w / l$ equal to 0.35 and 0.4 . It is obvious that the SCC determined to $1.4 \%$ by weight of cement has been an improvement in spread diameter of respectively $9.7 \%$ and $51.2 \%$ compared to those of SCC with an adjuvant dosage of $1.1 \%$ and $1.8 \%$ weight cement.

Figures 4 and $\mathbf{5}$ present a reducing in spread diameter when increasing the content of the aggregates. This increase is beneficial to the stability of the segregation rate. For a content of $0.04 \%$ in colloidal agent, the spread diameter and the rate of segregation are reduced respectively for $3.12 \%$ and $61.8 \%$ compared with those of SCC without colloidal agent.

\subsection{Compressive and Tensile Strengths}

Figures 6 and 7 show the plot of the average compressive and splitting tensile strength of different concrete mixtures. It can be noted that the incorporation of mineral additives in to the SCC mixes, increased the compressive and split tensile strength.

The compressive strengths of all the mixes have shown strength above $28 \mathrm{MPa}$ which is the required strength. There is a significant increase in the compressive strength of the concrete (scc4) with silica fume because of the high pozzolanic nature of the silica fume and its void filling ability.

The maximum 28-day cube compressive strength of 
scc4 with silica fume was $56 \mathrm{MPa}$ and of scc1, scc2, and scc3 was respectively $47 \mathrm{MPa}, 31 \mathrm{MPa}$ and $28 \mathrm{MPa}$.

It is clear that the role of silica fume seems to be more effective in strength compared to other mixes. The mix with silica fume has shown an improvement in compressive strength by about $90 \%$ and in tensile strength by about $70 \%$ compared to control test concrete at 28 days.

Generally all the strengths were increased gradually up to a maximum values corresponding to 28 days concrete after that no significant increase was observed.

\subsection{Ultrasonic Pulse Velocity}

Table 6 presents the relationship between the compressive strength and the ultrasonic pulse velocity of the SCC mixtures. The UPV values ranged from $4255 \mathrm{~m} / \mathrm{s}$ to 4438 $\mathrm{m} / \mathrm{s}$. The ordinary concrete mixture had the highest UPV value while the lowest UPV value was measured for the scc4 mixture. All measured UPV values are good values according to Whitehurst classification since they are greater than $3500 \mathrm{~m} / \mathrm{s}$. The increase in UPV was accompanied by an increase in the compressive strength. Similar results have been obtained by other researchers [19].

\section{Conclusions}

The obtained results show the effects of local materials on the properties of fresh and hardened concrete. It is shown that a good SCC could be obtained using appropriate materials contents. It could be concluded that all the mixtures had satisfactory self-compacting properties in the fresh state. The addition of limestone, silica fume and blast furnace slag had positive effects on the workability. The optimization of the bonding paste is obtained by using tests to Marsh cone. These tests are considered as a criterion to determine the best mineral admixture among LP, SF and BFS. Thus, one can say that SF is the most suitable for improving all of them.

The results for hardened properties of the SCC mixtures containing different mineral admixtures we investigated showed significant performances; and the highest compressive strength has been obtained for the SF mixtures.

There was a good correlation between the compression strength of self compacting concrete and pozzolanic nature (reactivity) of each mineral adjuvant.

We clearly demonstrated the possible manufacturing of self compacting concrete with fresh and hardened good rheological and mechanical properties using local materials. The improvement of mechanical and rheological properties has been obtained by reducing the water binding and using a super plasticizers and mineral additions. The mineral additions, namely silica fume, have shown an improvement in compressive and tensile strengths.

\section{REFERENCES}

[1] M. Liu, "Self-Compacting Concrete with Different Levels of Pulverized Fuel Ash,” Construction and Building Materials, Vol. 24, No. 7, 2010, pp. 1245-1252. doi:10.1016/j.conbuildmat.2009.12.012

[2] A. Leemann, R. Loser and B. Münch, "Influence of Cement Type on ITZ Porosity and Chloride Resistance of Self-Compacting Concrete," Cement \& Concrete Composites, Vol. 32, No. 2, 2010, pp. 116-120.

doi:10.1016/j.cemconcomp.2009.11.007

[3] S. C. Kou and C. S. Poon, "Properties of Self-Compacting Concrete Prepared with Coarse and Fine Recycled Concrete Aggregates," Cement \& Concrete Composites, Vol. 31, No. 9, 2009, pp. 622-627. doi:10.1016/j.cemconcomp.2009.06.005

[4] F. M. A. Filho, B. E. Barragán, J. R. Casas and A. L. H. C. El Debs, "Hardened Properties of Self-Compacting Concrete-A Statistical Approach," Construction and Building Materials, Vol. 24, No. 9, 2010, pp. 1608-1615. doi:10.1016/j.conbuildmat.2010.02.032

[5] O. Boukendakdji, S. Kenai, E. H. Kadri and F. Rouis, "Effect of Slag on the Rheology of Fresh Self-Compacted Concrete,” Construction and Building Materials, Vol. 23, No. 7, 2009, pp. 2593-2598. doi:10.1016/j.conbuildmat.2009.02.029

[6] B. Craeye, G. De Schutter, B. Desmet, J. Vantomme, G. Heirman, L. Vandewalle, O. Cizer, S. Aggoun and E. H. Kadri, "Effect of Mineral Filler Type on Autogenous Shrinkage of Self-Compacting Concrete," Cement and Concrete Research, Vol. 40, No. 6, 2010, pp. 908-913. doi:10.1016/j.cemconres.2010.01.014

[7] H. Okamura and M. Ouchi, "Self-Compacting Concrete. Development, Present Use and Future,” First International RILEM Symposium on Self-Compacting Concrete, Rilem Publications SARL, 1999, pp. 3-14.

[8] A. Neville, "Proprietés des Bétons," Centre de Recherche International du Béton, Editions Eyrolles, 2000.

[9] S. Assie, "Durabilité des Bétons Autoplacants," Ph.D. Thesis, INSA de Toulouse, France, No. 747, 2004.

[10] European Committee for Standardization, "Cement: Composition, Specifications and Conformity Criteria," Common Cements, 2000.

[11] B. Felekoglu, S. Turkel and B. Baradan, "Effect of Water/ Cement Ratio on the Fresh and Hardened Properties of Self-Compacting Concrete,” Build Environment, Vol. 42, No. 4, 2007, pp. 1795-802. doi:10.1016/j.buildenv.2006.01.012

[12] G. Ye, X. Liu, G. De Schutter, A. M. Poppe and L. Taerwe, "Influence of Limestone Powder Used as Filler in SCC on Hydration and Microstructure of Cement Pastes," Cement and Concrete Composites, Vol. 29, No. 2, 2007, pp. 94-102. doi:10.1016/j.cemconcomp.2006.09.003

[13] A. M. Poppe and G. D. Schutter, "Cement Hydration in the Presence of High Filler Contents," Cement and Concrete Research, Vol. 35, No. 12, 2005, pp. 2290-2299. doi:10.1016/j.cemconres.2005.03.008

[14] I. B. Topcu, T. Bilir and T. Uygunoglu, "Effect of Waste Marble Dust Content as Filler on Properties of Self-Com- 
pacting Concrete," Construction and Building Materials, Vol. 23, No. 5, 2009, pp. 1947-1953.

doi:10.1016/j.conbuildmat.2008.09.007

[15] S. Assie, G. Escadeillas and V. Waller, "Estimates of SelfCompacting Concrete 'Potential' Durability,” Construction and Building Materials, Vol. 21, No. 10, 2007, pp. 1909-1917. doi:10.1016/j.conbuildmat.2006.06.034

[16] O. Unal, I. B. Topcu and T. Uygunoglu, "Use of Marble Dust in Self Compacting Concrete," Proceedings of $\mathrm{V}$ Symposium MERSEM0 2006 on Marble and Natural Stone, Afyon, 2006, pp. 413-420.

[17] B. Felekoglu, K. Tosun, B. Baradan, A. Altun and B. Uyulgan, "The Effect of Fly Ash and Limestone Fillers on the Viscosity and Compressive Strength of Selfcompacting Repair Mortars," Construction and Building Materials, Vol. 36, No. 9, 2006, pp. 1719-1726.

[18] I. Turkmen, "Influence of Different Curing Conditions on the Physical and Mechanical Properties of Concretes with Admixtures of Silica Fume and Blast Furnace Slag,” Materials Letters, Vol. 57, No. 29, 2003, pp. 4560-4569. doi:10.1016/S0167-577X(03)00362-8

[19] M. Sahmaran, H. A. Christianto and I. O. Yaman, "The Effect of Chemical Admixtures and Mineral Additives on the Properties of Self-Compacting Mortars," Cement and
Concrete Composites, Vol. 28, No. 5, 2006, pp. 432-440. doi:10.1016/j.cemconcomp.2005.12.003

[20] V. B. Bosiljkov, "SCC Mixes with Poorly Graded Aggregate and High Volume of Limestone Filler," Cement and Concrete Research, Vol. 33, No. 9, 2003, pp. 1279-1286. doi:10.1016/S0008-8846(03)00013-9

[21] W. S. Aaron, M. J. Hamlin and P. S. Surenda, "New Methodology for Designing Self-Compacting Concrete,” ACI Materials Journal, Vol. 98, No. 6, 2001.

[22] K. B. Van, A. Yilmaz and P. S. Surendra, "Rheology Model for Self-Consolidating Concrete,” ACI Materials Journal, 2002.

[23] L. J. O’Flannery and M. M. O’Mahony, "Precise Shape Grading of Coarse Aggregate,” Magazine of Concrete Research, Vol. 51, No. 5, 1999, pp. 319-324. doi:10.1680/macr.1999.51.5.319

[24] K. Khayat, “Colloques sur les Bétons Autonivelants,” Centre de Recherche Interuniversitaire sur le Béton (CRIB), Université de Sherbrooke, Laval University, Québec, 1996.

[25] J. Nasvik, "The ABCs of SCC," Concrete Construction, 2002. 